\title{
Expression of lysyl oxidase and effect of copper chloride and ammonium tetrathiomolybdate on bovine ovarian follicle granulosa cells cultured in serum-free media
}

\author{
N. R. Kendall ${ }^{1,2}$, P. Marsters ${ }^{1}$, R. J. Scaramuzzi ${ }^{2}$ and B. K. Campbell ${ }^{1}$ \\ ${ }^{1}$ Division of Reproductive Medicine, School of Human Development, D Floor, East Block, Queen's \\ Medical Centre, Nottingham NG7 2UH, UK; and ${ }^{2}$ Division of Veterinary Basic Sciences, Royal \\ Veterinary College, Royal College Street, London NW1 OTU, UK
}

\begin{abstract}
Subfertility that will respond to appropriate copper supplementation is a widespread problem in the UK dairy herd and, although characterized by reduced or absent oestrus and reduced conception rates, the exact cause remains unknown. The aim of this study was to investigate the expression of mRNA for the copper-dependent enzyme, lysyl oxidase, and the effect of copper and/or copper chelating thiomolybdates on FSH-induced differentiation of bovine granulosa cells cultured in serum-free media. Expression of lysyl oxidase mRNA was investigated using bovine specific primers and RT-PCR on cell lysates obtained from bovine granulosa cells cultured under optimum conditions for $0,16,24,48,96,144$ and $192 \mathrm{~h}$. The effect of thiomolybdates and copper were investigated by supplementing optimized granulosa cell culture media with ammonium tetrathiomolybdate at $0,0.1,1,10,100$ and $1000 \mu \mathrm{g} \mathrm{ml}^{-1}$, copper chloride at equimolar concentrations $\left(0,0.0516,0.516,5.16,51.6,516 \mu \mathrm{g} \mathrm{ml}^{-1}\right)$ or equimolar combinations of both media. Lysyl oxidase
\end{abstract}

mRNA was expressed by the granulosa cells throughout the $192 \mathrm{~h}$ of culture. Thiomolybdate depressed oestradiol production in a dose-dependent manner at doses $>1 \mu \mathrm{g} \mathrm{ml}^{-1}$ and prevented the characteristic clumped appearance of granulosa cells in this serum-free system. Although the supplementation of copper alone had no effect at physiological doses, the use of the equimolar copper and thiomolybdate media ameliorated the effect of tetrathiomolybdates on both oestradiol production and cellular morphology. In conclusion, the results of the present study indicate that lysyl oxidase is expressed by granulosa cells, that thiomolybdates can prevent $\mathrm{FSH}$-induced differentiation of bovine granulosa cells in vitro and that these effects can be reversed by copper supplementation. Overall, these data support the hypothesis that copper-responsive subfertility results from perturbation of the normal pattern of ovulatory follicle growth and development, an effect that may be mediated, at least in part, via lysyl oxidase activity.

\section{Introduction}

A major problem in the UK is the declining fertility of the dairy herd (Royal et al., 2000). Although a multifactoral problem, the major focus has rightly been energy deficit, but a considerable proportion of animals have been shown to respond to appropriate copper supplementation (Kendall et al., 2001). The aetiology of the copperresponsive subfertility condition comprises reduced or absent oestrus and reduced conception rates (Phillippo et al., 1987). Mackenzie et al. (2001) showed that treatment with copper reduced the inseminations to confirmed conception from 2.5 to 1.7 for control and copper-treated cattle, respectively.

Under field conditions, most copper-responsive conditions are induced by molybdenum, which reacts with

Email: Nigel.Kendall@Nottingham.ac.uk sulphur in the rumen to form thiomolybdates, which in turn bind copper with high affinity (Dick et al., 1975). Thus, free copper in the rumen will form insoluble copper thiomolybdate and be excreted in the faeces, whereas excess thiomolybdate may be absorbed to react with copper within the metabolic system of the animal (Dick et al., 1975). Although investigated in the 1980s, the problem of molybdenum-induced subfertility is still widespread and in the field has been found to respond to appropriate copper supplementation (Black and French, 2000; Kendall et al., 2001). Copper deficiency induced by molybdenum supplementation of cattle has been shown experimentally to reduce fertility markedly (Phillippo et al., 1987). A molybdenum-induced copper depletion system has been used to show that a reduction in fertility is associated with reduced conception rates, anovulation, anoestrus, decreased basal $\mathrm{LH}$, a reduced peak surge of $\mathrm{LH}$ and a reduction in the numbers and 
frequency of LH pulses (Phillippo et al., 1987). Du Plessis et al. (1999a) reported that behavioural anoestrus occurs early in sheep fed a high molybdenum and sulphur diet, with true anoestrus occurring after a much longer period of supplementation in the trial. In addition, Du Plessis et al. (1999b) reported that the ovaries are reduced in size and have a decreased response to superovulation in the molybdenum and sulphur supplemented groups. The absence of oestrus in animals with copper-responsive subfertility could be attributed to either attenuation of the preovulatory oestradiol surge that induces oestrous behaviour and the $\mathrm{LH}$ surge or perturbation of the mechanisms within the central nervous system that result in the behavioural response to this endocrine stimulus (Alexander et al., 1980). The study of Moffor and Rodway (1991) investigated the effect of i.v. administration of tetrathiomolybdate to lambs but no effect of this treatment on either pulsatile $\mathrm{LH}$ or surge release of $\mathrm{LH}$ in response to $\mathrm{GnRH}$ or oestradiol challenge was reported. Therefore, these data would suggest that central effects of copper-responsive subfertility are unlikely.

Slee et al. (2001) have shown differential expression of the copper containing enzyme, lysyl oxidase, in rodent studies that sought to identify the genes associated with gonadotrophin-induced ovarian somatic cell differentiation. Lysyl oxidase is essential for the stabilization of the extracellular matrix $(E C M)$ as it is responsible for the cross-linking of collagen and elastin. Its action is via the oxidative deamination of peptidyl lysyl groups and its activity has been shown to be linked to increased copper intake (Rucker et al., 1998). Thiomolybdates have also been shown to affect lysyl oxidase and subsequent collagen and elastin formation, often observed as symptoms of clinical copper deficiency, which include cardiac problems, bone weakness and joint abnormalities (Underwood, 1981). Significantly, marked changes and remodelling of the ECM occur during ovarian follicle development (Rodgers et al., 1998). The ECM is also considered as an active regulator of cell migration, division, differentiation, death and anchorage. Collagen type IV, laminin and fibronectin have been reported to be secreted by cultured granulosa cells (Rodgers et al., 1995, 1996) and are thought to be present in lamina-like material in the theca matrix (Rodgers et al., 1999). The basal lamina seems to be constantly remodelled as the follicle matures (Rodgers et al., 1999) which may explain the differential expression of the lysyl oxidase reported by Slee et al. (2001).

It is our hypothesis that the effects of thiomolybdateinduced copper deficiency on fertility may be mediated by perturbation of lysyl oxidase activity and, hence, gonadotrophin-induced cellular differentiation. The aim of the present study was to test this hypothesis using a serum-free culture system that allows gonadotrophininduced differentiation of granulosa cells in vitro (Gutierrez et al., 1997a). Importantly, in this system, no attachment factors are added and the cells secrete their own ECM (B. K. Campbell, unpublished). The objectives of this study were to determine whether lysyl oxidase mRNA (LOX) was expressed by granulosa cells in this culture system and whether copper and thiomolybdate supplementation can affect FSH-induced granulosa cell differentiation in vitro.

\section{Materials and Methods}

\section{Expression of lysyl oxidase mRNA in granulosa cells}

Bovine ovaries were obtained from a commercial abattoir. Follicles between 2 and $5 \mathrm{~mm}$ in diameter were dissected from a number of ovaries to negate any individual animal effects, and granulosa cells were isolated using the procedure of Campbell et al. (1996). Briefly, the dissected follicles were hemisected in $\mathrm{dPBS}^{-}$, disaggregated by flushing through the barrel of a $1 \mathrm{ml}$ syringe and washed twice in culture media, before being resuspended and counted using a trypan blue viability stain. Granulosa cells were plated at a density of $5 \times 10^{5}$ cells per well in a 24-well flat bottom plate (Nunclon, Nunc) with $1 \mathrm{ml}$ of granulosa culture medium with optimum concentrations of insulin, human recombinant long R3-insulin-like growth factor (LR3IGF) and NIAMDD-FSH-S20 (ovine FSH) of 10, 1 and $1 \mathrm{ng} \mathrm{ml}^{-1}$, respectively (Gutierrez et al., 1997a), to induce differential granulosa cell expression. Media were changed at $48 \mathrm{~h}$ intervals (80\%) where appropriate. Cells from each well were harvested into $150 \mu$ l of lysis buffer (RNeasy ${ }^{\text {TM }}$ RTL Buffer, Qiagen, Crawley) after removal of culture media, which was retained and stored at $-20^{\circ} \mathrm{C}$ for subsequent oestradiol assay. For each time-point (16, 24, 48, 96, 144 and $192 \mathrm{~h}$ ), duplicate wells were pooled and retained at $-20^{\circ} \mathrm{C}$ for subsequent analysis by RTPCR. At the time of plate seeding, cells were isolated and lysed, and retained to give a zero (0) reference time-point. Total RNA was isolated from the time course samples using the RNeasy ${ }^{\mathrm{TM}}$ mini kit (Qiagen) and protocol. First strand cDNA synthesis was performed using Revertaid ${ }^{\mathrm{TM}} \mathrm{H}$-minus reverse transcriptase (MBI). Random hexamers (Promega, Southampton) were used to prime the CDNA strand as an $18 \mathrm{~S}$ internal standard (QuantumRNA ${ }^{\mathrm{TM}} 18 \mathrm{~S}$ rRNA Universal internal standard, Ambion, Huntington) was used. PCR amplification was performed using cDNA-distinguishing primers. Bovine specific primers were designed and synthesized, and after partial sequencing of bovine lysyl oxidase cDNA (P. Marsters, N. R. Kendall and B. K. Campbell, unpublished), the sense primer was on exon 3 (5'TTCCTACCAAGTCGACCAAGA-3') and the antisense primer on exon 6 (5'-TGCATAAGCGTGATGTCCTG-3') and formed a 399 base pair PCR amplicon. The bovine product has $86.25 \%$ homology to the rat sequence. The PCR products were subjected to electrophoresis on $3 \%$ agarose gels containing ethidium bromide and visualized under UV light. 
Effects of thiomolybdates and copper on cultured granulosa cells

Granulosa cells were isolated as described previously and plated at a density of 75000 cells per well (300000 cells $\mathrm{ml}^{-1}$ ) in a 96-well flat bottom plate (Nunclon, Nunc) with $250 \mu$ l granulosa culture medium with optimum concentrations of insulin, LR3-IGF and NIAMDD-FSH-S20 (ovine FSH) of 10, 1 and $1 \mathrm{ng} \mathrm{ml}^{-1}$, respectively (Gutierrez et al., 1997a), to induce granulosa cell differentiation. Treatments were applied to four wells per replicate plate (four plates) as follows: ammonium tetrathiomolybdate $\left((\mathrm{NH} 4)_{2} \mathrm{MoS}_{4}\right)$ (Sigma-Aldrich, Poole) was added to the media at concentrations of $0,0.1$, 1.0, 10.0, 100.0 and $1000.0 \mu \mathrm{g} \mathrm{ml}^{-1}$ (termed TTM-0, TTM-0.1, TTM-1, TTM-10, TTM-100 and TTM-1000, respectively), tissue culture grade copper chloride hydrate $\left(\mathrm{CuCl}_{2}\right)$ (Sigma-Aldrich, Poole) was added at equimolar equivalents with concentrations of $0,0.0516,0.516$, 5.16, 51.6 and $516.0 \mu \mathrm{g} \mathrm{ml}^{-1}$ (termed Cu-0, Cu-0.1, Cu-1, Cu-10, Cu-100 and Cu-1000, respectively) and equimolar concentrations of the two compounds in combination were added to the media to form CuTTM0, CuTTM-0.1, CuTTM-1, CuTTM-10, CuTTM-100 and CuTTM-1000 treatments. The cells were cultured for $192 \mathrm{~h}$ with $175 \mu \mathrm{l}(70 \%)$ of media that was replaced with fresh treatment media at $48 \mathrm{~h}$ intervals. The removed medium was retained and stored at $-20^{\circ} \mathrm{C}$ for subsequent analysis of oestradiol concentrations. The numbers of cells were estimated using the neutral red cell viability stain at the end of the culture (192 h) (Campbell et al., 1996).

\section{Oestradiol assay}

Oestradiol concentrations were assayed using a previously validated double-antibody radioimmunoassay (Webb et al., 1985). The sensitivity of the assay was $39 \mathrm{pg} \mathrm{ml}^{-1}$ and the intra- and interassay coefficients of variation were 14.7 and $16.3 \%$, respectively. Oestradiol concentrations were expressed as total production for all time-points and the oestradiol concentration at $192 \mathrm{~h}$ was also expressed on a 'per cell' basis. All oestradiol concentrations were natural log transformed to obtain a normal distribution before statistical analysis.

\section{Statistical analysis}

Statistical analysis was carried out on SPSS using univariate GLM for single time-point analysis and repeated measures GLM for multi-time point analysis. The analysis was blocked by individual culture plate. Individual group comparisons were carried out using the Bonferroni method.

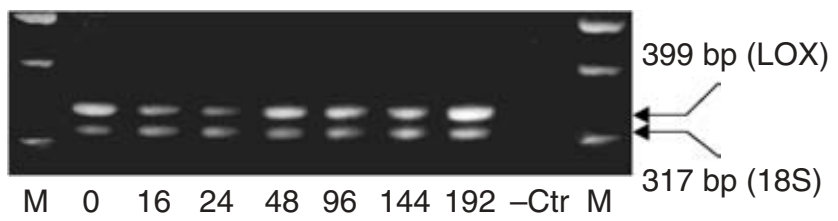

Fig. 1. The gel product of PCR showing the lysyl oxidase mRNA (LOX) (399 bp) and 18S internal standard (317 bp) amplicons from bovine granulosa cells cultured in optimum serum-free conditions for 0, 16, 24, 48, 96, 144 and 192 h. -Ctr: negative control; M: marker lanes.

\section{Results}

\section{Expression of lysyl oxidase}

The morphology and induction profile of the culture used for the expression of LOX was normal with the usual characteristic increased production of oestradiol after $48 \mathrm{~h}$, reaching a peak at $144 \mathrm{~h}$ (data not shown). The gel product of the PCR reaction is shown (Fig. 1). Lysyl oxidase (399 bp amplicon) and the $18 \mathrm{~S}$ internal positive control (317 bp amplicon) are expressed across all the time-points $(0,16,24,48,96,144$ and $192 \mathrm{~h})$ of the culture. There was no PCR product within the negative control lane.

\section{Cellular morphology}

Normal cellular morphology (characteristic clumped phenotype with aggregations of rounded follicular cells attached to the surface of the plate by elongated fibroblastic like cells; Gutierrez et al., 1997b) was evident after $192 \mathrm{~h}$ of culture in the control cells and in cells exposed to doses of up to and including TTM-1 (Fig. 2a). A dose of TTM-10 resulted in a marked reduction in cellular clumping, whereas clumping was absent for the TTM-100 and -1000 doses (Fig. 2a). The effect of the addition of copper to the media is shown (Fig. 2b), and the presence of equimolar copper at the 10 and 100 dose of TTM resulted in more cellular clumping compared with TTM alone at these doses.

\section{Oestradiol production}

Granulosa cells from small antral follicles cultured in serum-free medium in the presence of optimal doses of FSH, insulin and IGF-I that were shown previously to induce cellular differentiation (Gutierrez et al., 1997a) displayed the expected induction of oestradiol production with increasing time in culture, and maximal production was observed between 144 and $192 \mathrm{~h}$ of culture (Fig. 3a). The 0.1 and 1.0 doses of TTM had little effect on this induction profile. However, increasing doses of TTM led to a significant $(P<0.001)$ dose-dependent decrease in oestradiol production at all time-points (48, 96, 144 and 192 h; Fig. 2b). 
(a)
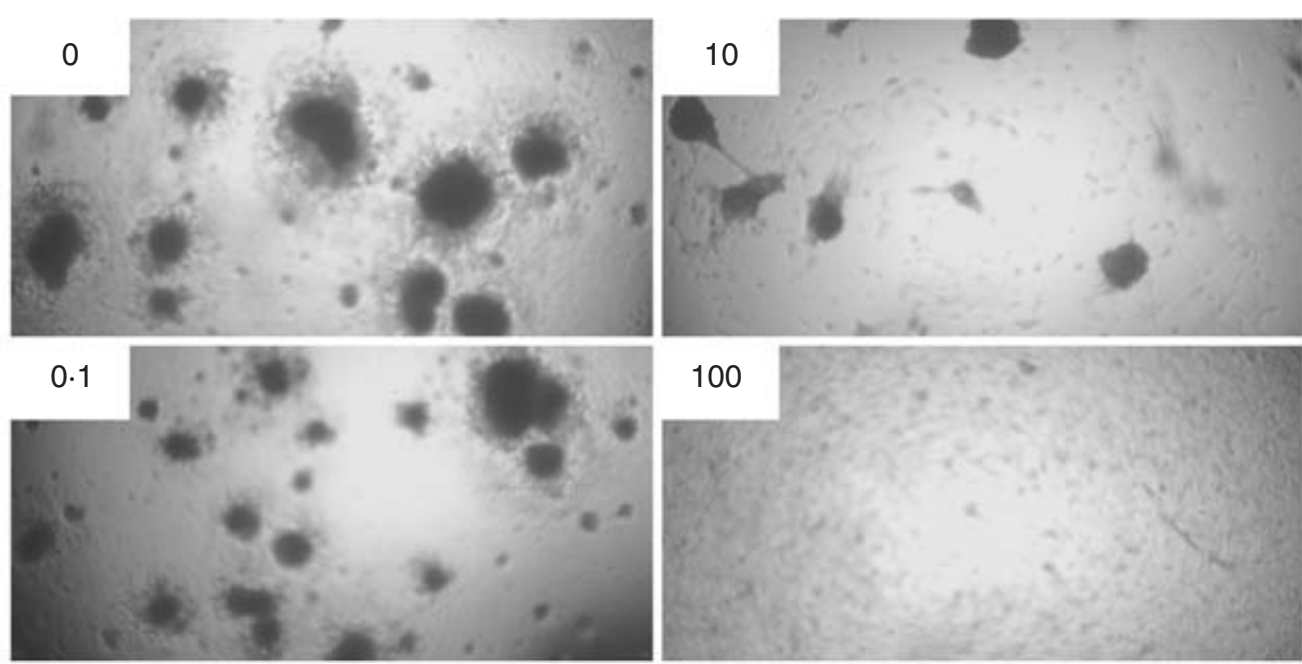

100
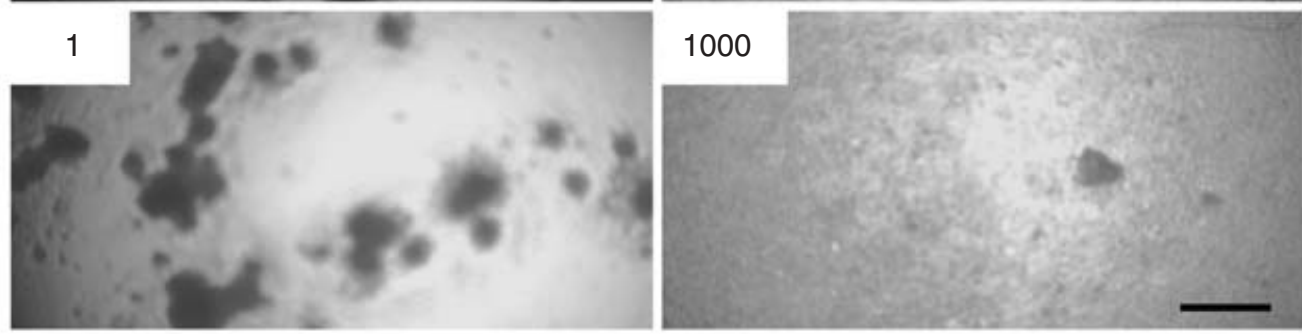

(b)
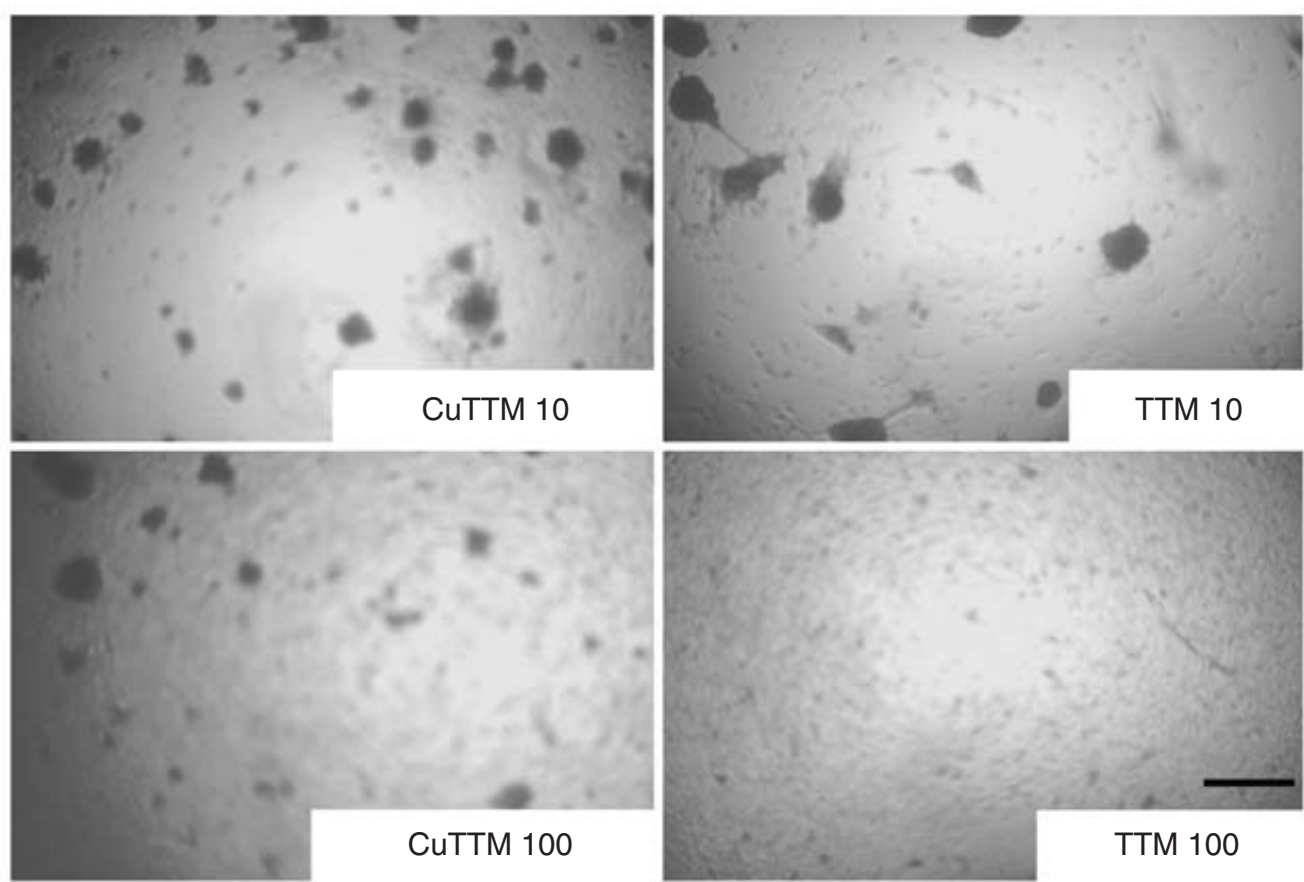

Fig. 2. The morphology of bovine granulosa cells photographed at $192 \mathrm{~h}$ of culture. (a) The effect of increasing the dose of tetrathiomolybdate from 0 to $1000 \mu \mathrm{g} \mathrm{ml}-1$ on the characteristic cell clumping. (b) The ameliorating effect of copper (Cu) (images on left) on thiomolybdate (TTM) at doses of 10 and $100 \mu \mathrm{g} \mathrm{ml}^{-1}$. Scale bar is the same for all constitutive images and represents $50 \mu \mathrm{m}$. 
(a)

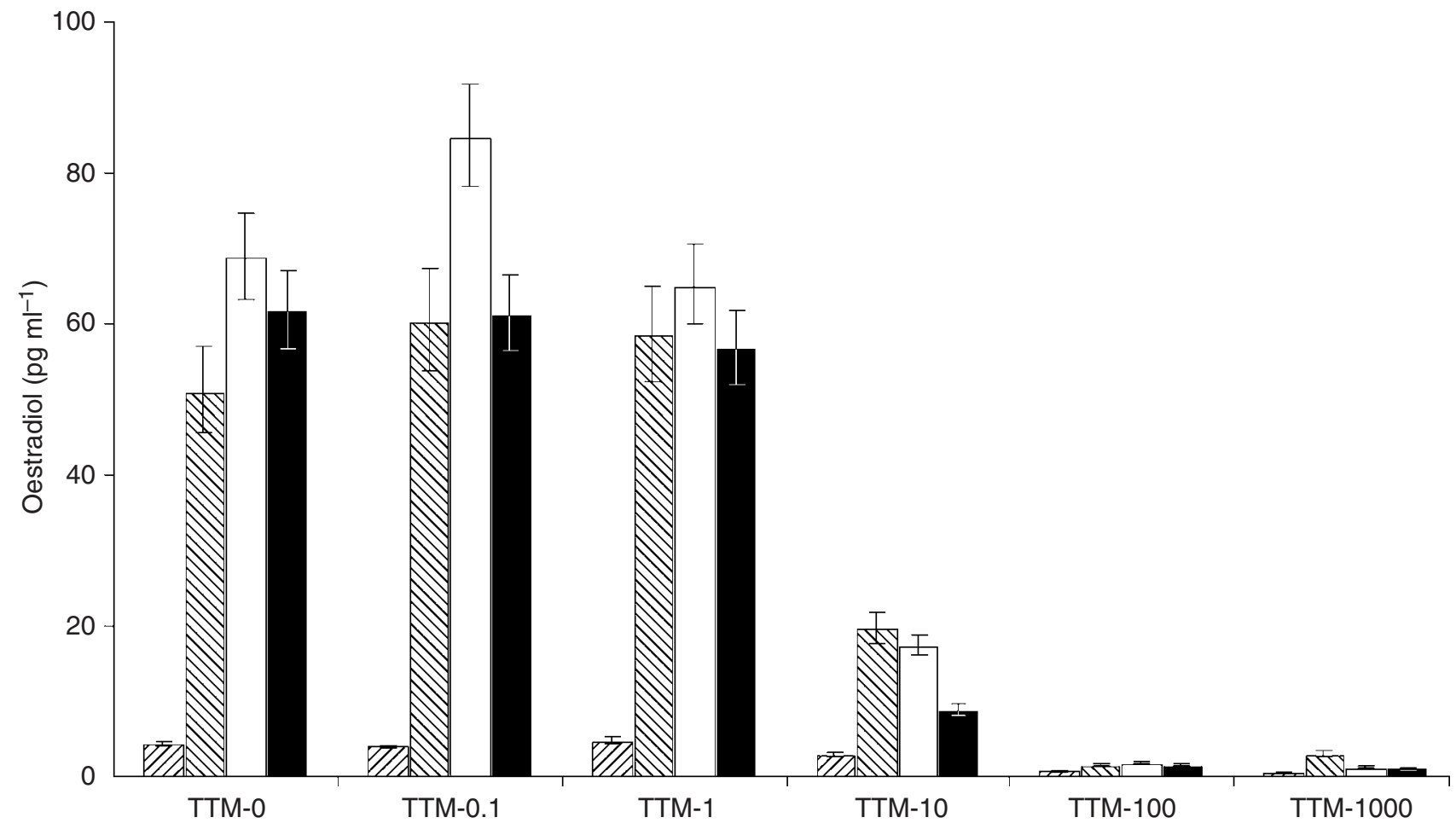

(b)

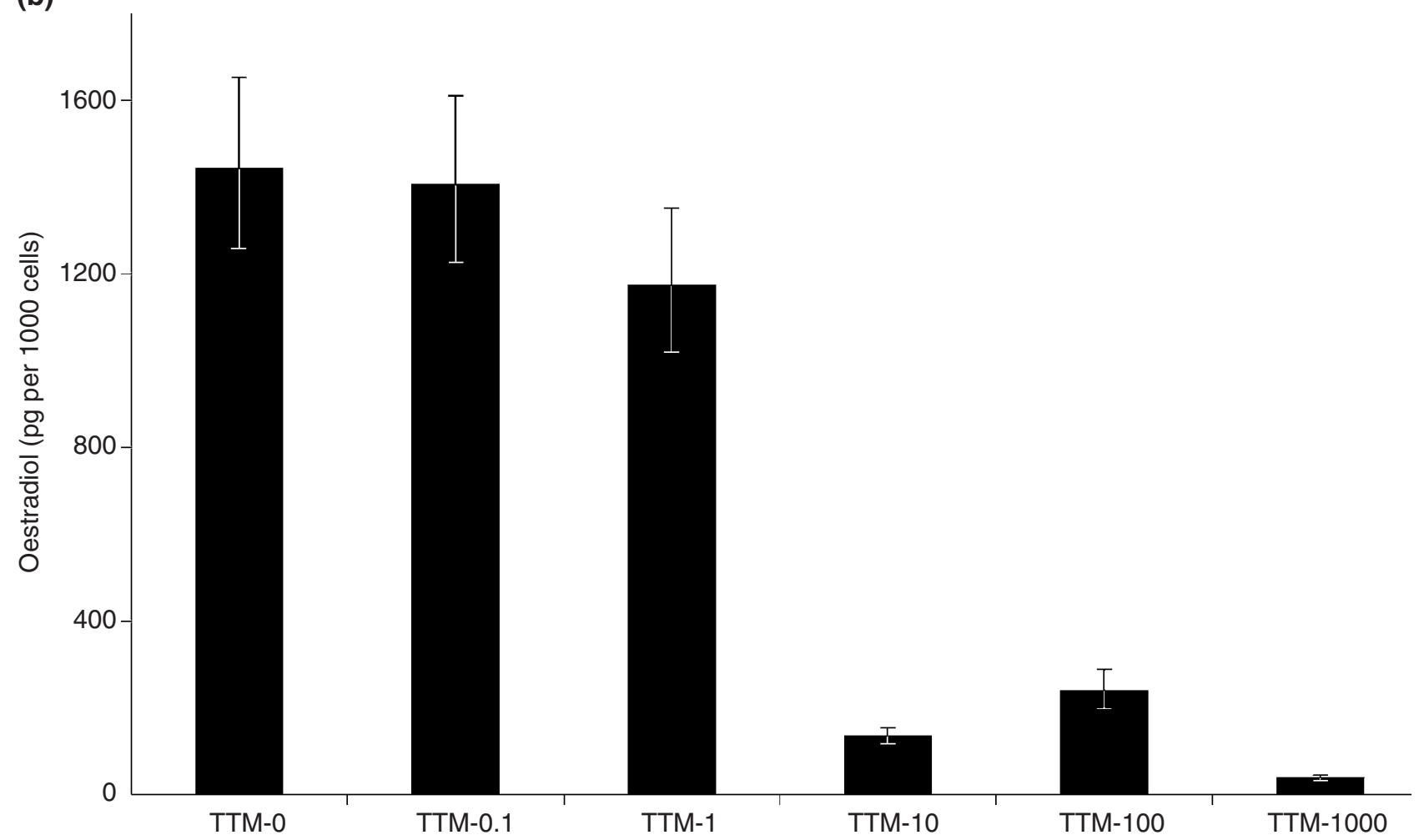

Fig. 3. The mean oestradiol production $\left(\mathrm{pg} \mathrm{ml}^{-1}\right)( \pm \mathrm{SEM})$ of bovine granulosa cells cultured under optimum serum-free conditions

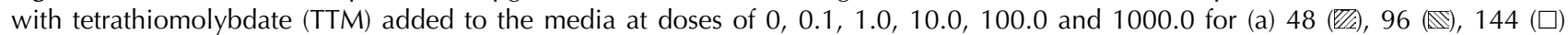
and 192 (ם) h and (b) $192 \mathrm{~h}$ corrected for the number of cells (pg per 1000 cells). 


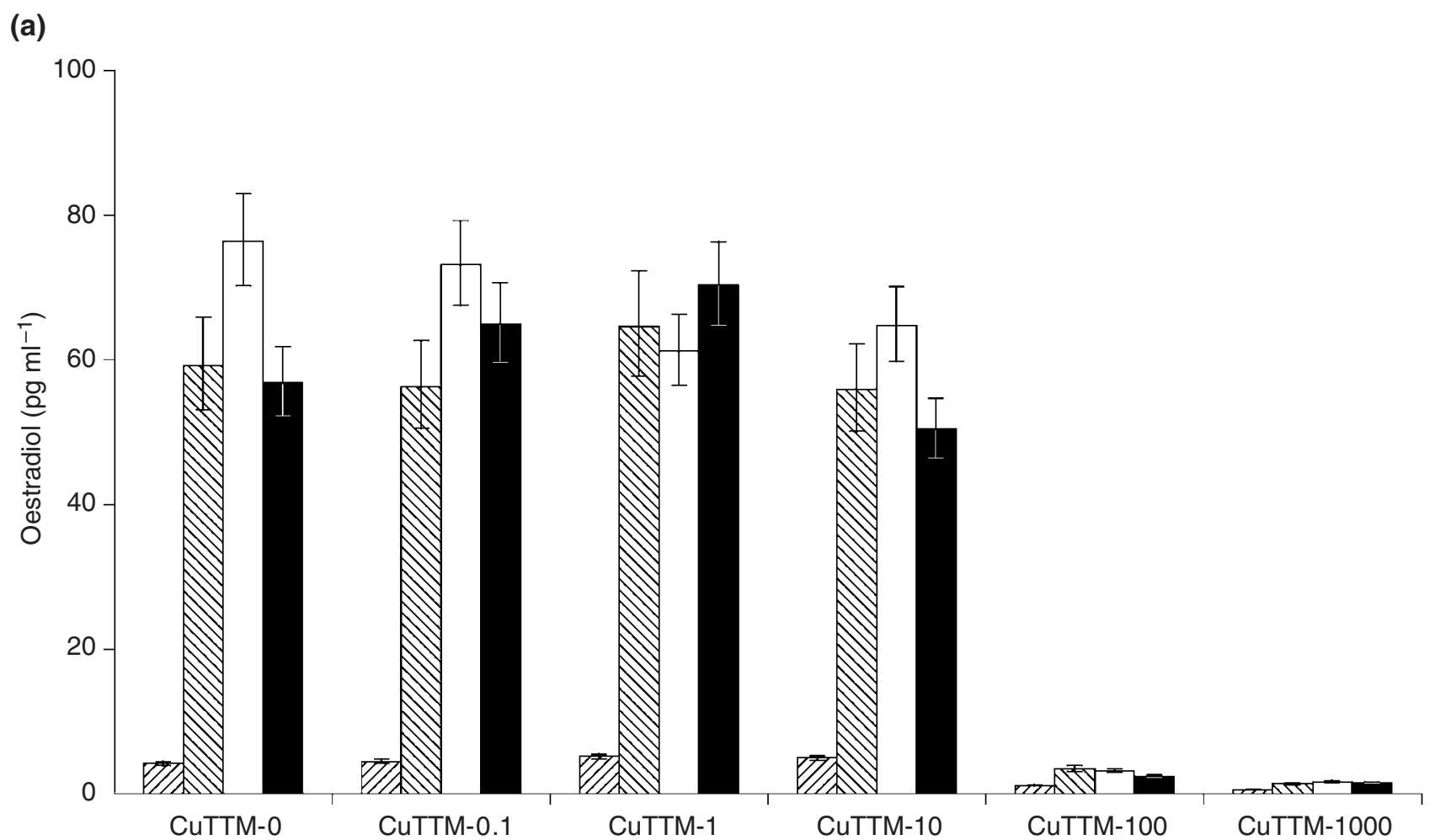

(b)

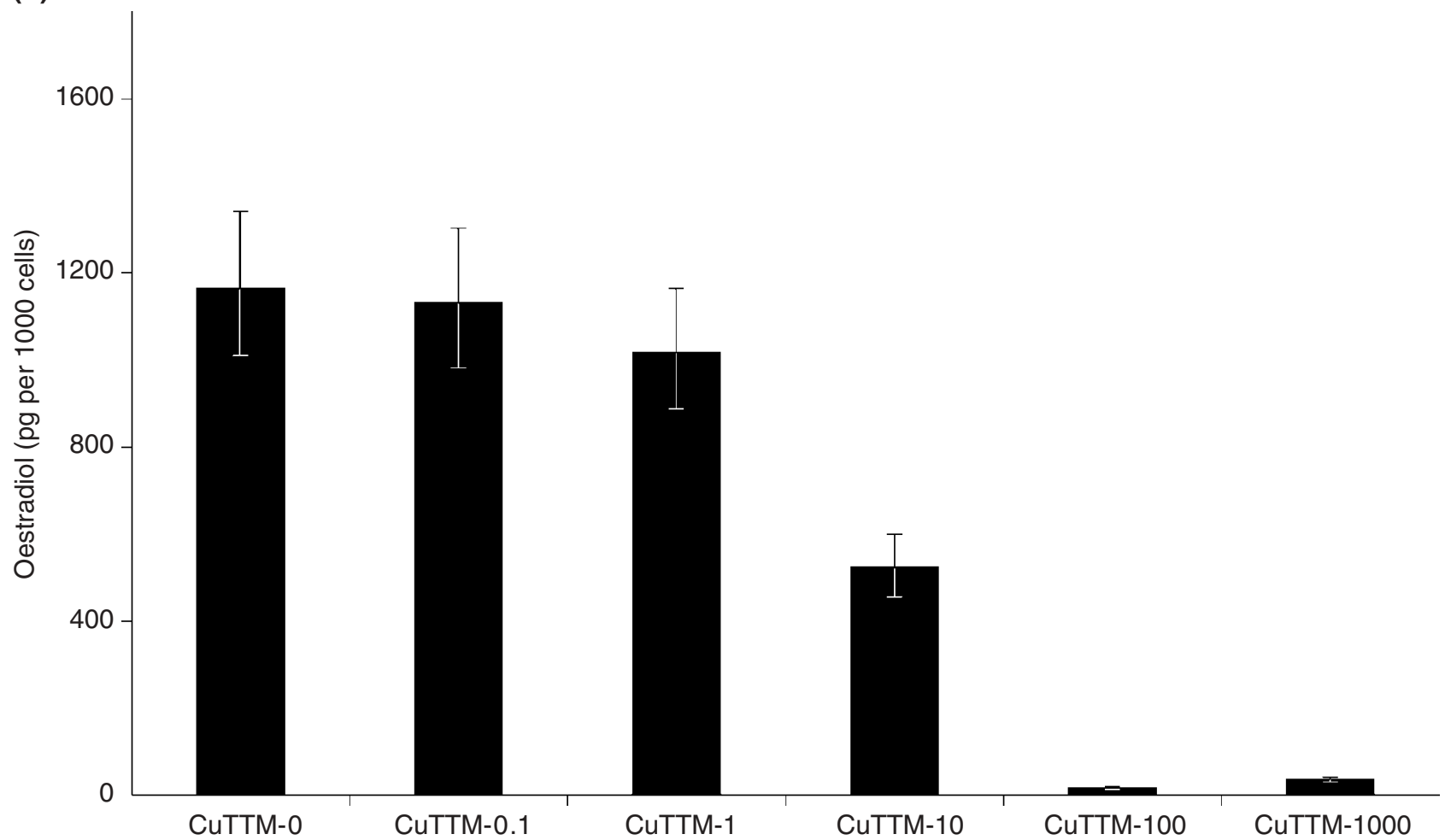

Fig. 4. The mean oestradiol production $\left(\mathrm{pg} \mathrm{ml}^{-1}\right)( \pm \mathrm{SEM})$ of bovine granulosa cells cultured under optimum serum-free conditions with copper and tetrathiomolybdate (CUTTM) at doses of 0, 0.1, 1.0, 10.0, 100.0 and 1000.0 added to the media for (a) 48 (R2a), $96(\mathbb{N}), 144(\square)$ and $192(\mathbb{\square}) \mathrm{h}$ and (b) $192 \mathrm{~h}$ corrected for the number of cells (pg per 1000 cells). 
Correction of these data for the number of cells after $192 \mathrm{~h}$ of culture (Fig. 3b) had no effect on the overall pattern of oestradiol production, and doses of TTM $>10$ resulted in a marked inhibition in oestradiol production $(P<0.001)$.

Copper alone had no significant effect on oestradiol production at any dose (data not shown) except for the 1000 dose, which appeared to be toxic to the cells and consequently oestradiol production was significantly reduced $(P<0.001)$.

The effect of combining copper and TTM on oestradiol production is shown (Fig. 4). These results show a similar pattern as for TTM alone with the exception of the CuTTM-10 combination. Thus, at 0 and low doses of CUTTM, the oestradiol induction profile was unaffected, whereas the CUTTM-100 and -1000 doses resulted in a marked inhibition $(P<0.001)$ of aromatase activity (Fig. 4a). However, in contrast to TTM-10 alone, the combined CuTTM10 dose had no effect on the oestradiol induction profile when compared with 0 doses (Fig. 4a). However, when examined on a per cell basis at $192 \mathrm{~h}$ of culture (Fig. 4b), the CUTTM-10 dose significantly reduced oestradiol production per cell $(P<0.05)$ compared with the CuTTM-0 and 0.1 doses, but compared with CUTTM-1 the decrease was not significant. This lack of significance was due to an apparent increase in the number of cells (not shown). However, the magnitude of this depression was much less $(P<0.001)$ than that for TTM-10 alone when expressed on a per cell basis (Fig. 3b). A comparison of the effect of copper and TTM, alone and in combination, on oestradiol production after $144 \mathrm{~h}$ at the 10 dose is shown (Fig. 5). These data further confirm that $\mathrm{Cu}-10$ alone had no effect on oestradiol production and that the same dose in combination with TTM was able to ameliorate the depressive effect of TTM-10 alone $(P<0.001)$.

\section{Discussion}

The results of the present study show that TTM is able to prevent $\mathrm{FSH}$-induced differentiation of bovine granulosa cells in culture. Furthermore, the experiments demonstrated that (i) the copper-dependent enzyme lysyl oxidase is expressed by granulosa cells; (ii) copper can ameliorate the effect of TTM; and (iii) TTM alters the morphology of the cultured cells. Overall, these results support the hypothesis that the effect of TTM may be mediated, at least in part, via lysyl oxidase activity.

The differentiation of the granulosa cells in serumfree culture medium in response to FSH and optimum insulin and IGF has been reported by Gutierrez et al. (1997a,b), who observed a characteristic appearance of tight aggregates (clumps) of spherical cells growing on top of enlarged flattened fibroblast-like cells during granulosa cell differentiation. Oestradiol production by these cells remains low for the first $48 \mathrm{~h}$

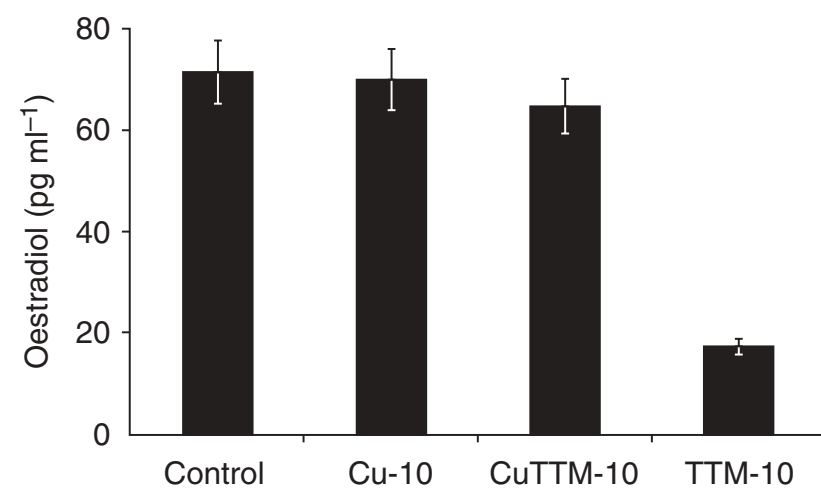

Fig. 5. The mean effects ( \pm SEM) on oestradiol production (pg $\mathrm{ml}^{-1}$ ) at $144 \mathrm{~h}$ of culture of the three different treatments (Cu: copper; TTM: tetrathiomolybdate; and CUTTM: copper and tetrathiomolybdate) at the 10 dose compared with a control (without copper or TTM), illustrating the ameliorating effect of the copper on steroid production.

of culture, but then increases exponentially up to $144 \mathrm{~h}$ of culture, followed normally by a plateau or slight decrease thereafter. Within this experiment normal induction profiles of oestradiol and cellular morphology were observed in the absence of thiomolybdates or high doses of copper. Thiomolybdate disrupted this characteristic morphological effect in a dose-responsive manner, and doses above $1 \mu \mathrm{g} \mathrm{ml}^{-1}$ resulted in a coincident decrease in oestradiol production. When copper was in combination with the thiomolybdate in the media, more cellular clumps were observed at lower concentrations of thiomolybdate and oestradiol production was increased, indicating an ameliorating effect of the copper. This effect of copper is consistent with the contention that the copper in the combined media binds to the thiomolybdate, which has a very high affinity for copper, forming an insoluble copper-thiomolybdate complex (Dick et al., 1975). Thiomolybdate that is not bound to the 'free' copper may also bind to copper within 'enzymes' including lysyl oxidase, as thiomolybdates have been shown to bind to caeruloplasmin, another copperdependent enzyme (Ogra et al., 1999). The fact that the equimolar doses of copper and thiomolybdate do not completely counteract the thiomolybdate effect indicates that either forming the copper thiomolybdate complex requires an excess of copper or that an equilibrium between copper in the media and copper in the biological systems is achieved. Further work is required to determine the effects of increased ratios of copper to thiomolybdate.

It is possible that the effect of thiomolybdates on cellular morphology outlined above is mediated by lysyl oxidase, as thiomolybdates have been reported to exert effects on lysyl oxidase (Suttle and Underwood, 1999). However, this does not rule out the possibility that other copper-dependent enzyme systems are involved. A further supporting mechanism is that the serum-free 
culture system used in these experiments has no external attachment factors (such as serum) for plate attachment and the system relies on the secretion of the ECM by the cells in culture (B. K. Campbell, unpublished). As the system requires the formation of an ECM, lysyl oxidase would be required to cross-link the collagen and elastin within the secreted matrix, and the fact that granulosa cells express mRNA for LOX throughout the culture period supports this hypothesis. The importance of the morphological changes that result in the formation of cellular clumps to the mechanism of somatic cell differentiation has been clarified by the finding that reestablishment of cell-cell contact is associated with reinitiation of normal patterns of expression for $\mathrm{FSH}$ and IGF receptors during the initial stages of culture (Marsters et al., in press). Furthermore, this increase in receptor gene expression occurred before induction of aromatase activity in the granulosa cells. Therefore, it would appear that cellular morphology and communication represent an important aspect of granulosa cell differentiation and hence normal development of the preovulatory follicle.

The effect of thiomolybdates on the whole animal has been shown to include reduced conception rates, anovulation and anoestrus, which are associated with a decreased release of LH (Phillippo et al., 1987). The results from the present study showing that TTM can inhibit gonadotrophin-induced induction of oestradiol production by granulosa cells are consistent with a direct effect of molybdenum-induced copper deficiency on the development of the preovulatory follicle. In ruminants, the dominant follicle is the source of over $96 \%$ of ovarian oestradiol secretion (Baird and Scaramuzzi, 1976) and the preovulatory oestradiol peak is the endocrine signal responsible for induction of both behavioural oestrus and the preovulatory LH surge (Baird and McNeilly, 1981). Therefore, interference with the normal development of this follicle would be expected to perturb both behavioural oestrus and ovulation to various extents, as has been observed in animals with molybdenuminduced copper responsive subfertility (Phillippo et al., 1987; Du Plessis et al., 1999a,b). Furthermore, it is well established that ovarian oestradiol plays a key role in controlling gamete transport and in priming the uterus for implantation, so that even if ovulation does occur, fertility rates are likely to be impaired if preovulatory oestradiol production is sub-optimal (Hafez, 1980). Again, this is one of the key symptoms of copperresponsive subfertility (Du Plessis et al., 1999a) and further studies are required to examine the effects of molybdenum-induced copper deficiency on the pattern of development and steroidogenic capacity of ovulatory follicles in vivo.

One possible criticism of this work is that the doses of TTM and copper used in vitro were not at physiological concentrations. The normal molybdenum concentration in bovine blood ranges from 0.05 to $3.0 \mu \mathrm{g}$ $\mathrm{ml}^{-1}$ (Mills and Davis, 1987); this would equate, if all molybdenum in the blood was in the form of tetrathiomolybdates and there was no copper present in the blood, to an equivalent of a TTM-0.14 to TTM-8.1. Although it is not known whether the higher of these so called 'normals' were suffering clinical symptoms of copper deficiency (thiomolybdate toxicity) these results do indicate that effects of thiomolybdates were observed to doses that were physiologically appropriate. Similarly, concentrations of copper found in bovine plasma normally range from 0.6 to $1.5 \mu \mathrm{g} \mathrm{ml}^{-1}$ (Underwood, 1981), equivalent to a Cu-0.31 to Cu-0.77 dose and the McCoys 5 a media has no supplemental copper salts. Therefore, it is clear that the doses of copper used in the present study were in the physiological range, with the exception of the highest $\mathrm{Cu}-1000$ dose which was clearly toxic to the cells. One potential problem with the use of these compounds is that both the TTM (yellowred) and Cu-TTM (deep red) may interfere with the neutral red cell viability stain to give erroneously high cell viabilities at higher concentrations. Investigation of this possibility showed that this was potentially a problem only at the high concentrations for each compound and that the magnitude of this effect on the overall results was minimal as a result of the very low oestradiol production by cells exposed to these doses (N. R. Kendall and B. K. Campbell, unpublished).

Although it has been possible to show that the granulosa cells maintained in this serum-free system express LOX, no attempt was made to determine whether thiomolybdates can alter the expression of LOX mRNA, as the effects observed in the present study are hypothesized to be mediated by the corruption of 'active' lysyl oxidase by the thiomolybdate. Therefore, further work is required to develop an assay system for the lysyl oxidase to test the hypothesis that the effects of thiomolybdates on granulosa cell morphology and differentiation are mediated via enzyme activity.

In conclusion, the results of the present study show that copper-dependent enzyme, lysyl oxidase, is expressed by granulosa cells, that the copper chelating thiomolybdate can prevent $\mathrm{FSH}$-induced differentiation of bovine granulosa cells in vitro and that these effects can be reversed by copper supplementation. Overall, these data support the hypothesis that copper-responsive subfertility results from perturbation of the normal pattern of ovulatory follicle growth and development, an effect that may be mediated, at least in part, via lysyl oxidase activity.

The authors wish to thank the National Institute of Health for the FSH preparation and BBSRC for funding N. R. Kendall. The technical assistance of I. Sfontouris is much appreciated.

\section{References}

Alexander G, Signoret JP and Hafez ESE (1980) Sexual, maternal and neonatal behavior. In Reproduction in Farm Animals 4th Edn. pp 304 334 Ed. ESE Hafez. Lea and Febiger, Philadelphia 
Baird DT and McNeilly AS (1981) Gonadotrophic control of follicular development and function during the oestrous cycle of the ewe Journal of Reproduction and Fertility Supplement 30 119-133

Baird DT and Scaramuzzi RJ (1976) The source of ovarian oestradiol and androstenedione in the sheep during the luteal phase Acta Endocrinologica (Copenhagen) 83 402-409

Black DH and French NP (2000) Copper supplementation and bovine pregnancy rates: three types of supplementation compared in comercial dairy herds Irish Veterinary Journal 53 213-222

Campbell BK, Scaramuzzi RJ and Webb R (1996) Induction and maintenance of oestradiol and immuno-reactive inhibin production with FSH by ovine granulosa cells cultured in serum free media Journal of Reproduction and Fertility 106 7-16

Dick AT, Dewey DW and Gawthorne JM (1975) Thiomolybdates and the copper-molybdenum-sulphur interaction in ruminant nutrition Journal of Agricultural Science 85 567-568

Du Plessis SS, Van Niekerk FE and Coetzer WA (1999a) The effect of dietary molybdenum and sulphate on the oestrus cycle and ovulation in ewes after manipulation with exogenous progesterone alone or in combination with FSH and LH Small Ruminant Research 33 63-69

Du Plessis SS, Van Niekerk FE and Coetzer WA (1999b) The effect of dietary molybdenum and sulphate on the sexual activity and plasma progesterone concentrations of ewes Small Ruminant Research 33 71-76

Gutierrez CG, Campbell BK and Webb R (1997a) Development of a longterm bovine granulosa cell culture system: induction and maintenance of oestradiol production, response to $\mathrm{FSH}$ and morphological characteristics Biology of Reproduction $\mathbf{5 6}$ 608-616

Gutierrez CG, Glazyrin AL, Robertson GW, Campbell BK, Gong JG, Bramley TA and Webb R (1997b) Ultra-structural characteristics of bovine granulosa cells associated with maintenance of oestradiol production in vitro. Molecular and Cellular Endocrinology 134 51-58

Hafez ESE (1980) Transport and survival of gametes. In Reproduction in Farm Animals 4th Edn. pp 203-225 Ed. ESE Hafez. Lea and Febiger, Philadelphia

Kendall NR, Illingworth DV and Telfer SB (2001) Copper responsive infertility in British cattle: the use of a blood caeruloplasmin to copper ratio in determining a requirement for copper supplementation. In Fertility in the High-Producing Dairy Cow Occasional Publication No. 26 Vol. 2 pp 429-432 Ed. MG Diskin. British Society of Animal Science, Edinburgh

Mackenzie AM, Moeini MM and Telfer SB (2001) The effect of a copper, cobalt and selenium bolus on fertility and trace element status of dairy cattle. In Fertility in the High-Producing Dairy Cow Occasional Publication No. 26 Vol.2 pp 423-427 Ed. MG Diskin. British Society of Animal Science, Edinburgh

Marsters P, Kendall NR and Campbell BK Temporal relationship between FSH receptor, type 1 insulin-like growth factor receptor, and aromatase expression during $\mathrm{FSH}$-induced differentiation of bovine granulosa cells maintained in serum-free culture Molecular and Cellular Endocrinology (in press)
Mills CF and Davis GK (1987) Molybdenum. In Trace Elements in Human and Animal Nutrition Vol. 1 pp 429-464 Ed. W Mertz. Academic Press Inc., San Diego

Moffor FM and Rodway RG (1991) The effect of tetrathiomolybdate on growth rate and onset of puberty in ewe-lambs British Veterinary Journal 147 421-431

Ogra Y, Komada Y and Suzuki KT (1999) Comparative mechanism and toxicity of tetra- and dithiomolybdates in the removal of copper Journal of Inorganic Biochemistry 75 199-204

Phillippo M, Humphries WR, Atkinson T, Henderson GD and Garthwaite PH (1987) The effect of dietary molybdenum and iron on copper status, puberty, fertility and oestrous cycles in cattle Journal of Agricultural Science (Cambridge) 109 321-336

Rodgers HF, Lavranos TC, Vella CA and Rodgers RJ (1995) Basal lamina and other extracellular matrix produced by bovine granulosa cells in anchorage independent culture Cell and Tissue Research 282 463-471

Rodgers RJ, Vella CA, Rodgers HF, Scott K and Lavranos TC (1996) Production of extracellular matrix fibronectin, and steroidogenic enzymes, and growth of bovine granulosa cells in anchorage-independent culture Reproduction, Fertility and Development 8 249-257

Rodgers HF, Irvine CM, van Wezel IL, Lavranos TC, Luck ML, Sado Y, Ninomiyia Y and Rodgers RJ (1998) Distribution of the alpha 1 to alpha 6 chains of type IV collagen in the bovine follicles Biology of Reproduction 59 1334-1341

Rodgers RJ, van Wezel IL, Irving-Rodgers HF, Lavranos TC, Irvine CM and Krupa M (1999) Roles of extracellular matrix in follicle development Journal of Reproduction and Fertility Supplement 54 343-352

Royal MD, Darwash AO, Flint APE, Webb R, Woolliams JA and Lamming GE (2000) Declining fertility in dairy cattle: changes in traditional and endocrine parameters of fertility Animal Science $\mathbf{7 0}$ 487-501

Rucker RB, Kosonen T, Clegg MS, Mitchell AE, Rucker BR, Urie-Hare JY and Keen CL (1998) Copper, lysyl oxidase and extracellular matrix protein cross-linking American Journal of Clinical Nutrition 67 996S-1002S

Slee RB, Hillier SG, Largue P, Harlow CR, Miele G and Clinton M (2001) Differentiation-dependant expression of connective tissue growth factor and lysyl oxidase messenger ribonucleic acids in rat granulosa cells Endocrinology 142 1082-1089

Suttle NF and Underwood EJ (1999) The Mineral Nutrition of Livestock 3rd Edn. pp 283-343 CABI, Oxon

Underwood EJ (1981) The Mineral Nutrition of Livestock 2nd Edn. pp 91 $108 \mathrm{CABI}$, Oxon

Webb R, Baxter G, McBride D, Nordblom GD and Shaw MPK (1985) The measurement of testosterone and estradiol-17-beta using iodinated tracers and incorporating an affinity-chromatography extraction procedure Journal of Steroid Biochemistry and Molecular Biology 23 10431051

Received 9 December 2002.

First decision 16 January 2003.

Revised manuscript received 29 January 2003.

Accepted 3 February 2003. 